\title{
The Impact of S-Commerce Usage in Indonesia Towards Social Commerce Intention (Case Study on TikTok)
}

\author{
Anggit Saghfira ${ }^{1, *}$ Rifelly Dewi Astuti ${ }^{2}$ \\ ${ }^{1,2}$ University of Indonesia, Indonesia \\ *Corresponding author. Email: anggit.saghfira@ui.ac.id
}

\begin{abstract}
This study aims to investigate the role of social commerce construct (SCCs) in influencing emotional support, informational support, perceived usefulness, and perceived risk, which will increase trust in the buying process through TikTok s-commerce in Indonesia. This study was obtained by an online survey answered by 305 respondents with criteria as TikTok users and have made a purchase process on TikTok at least once in the last three months. The results using SmartPLS 3.0 from 15 proposed hypotheses indicate two not significant hypotheses: emotional and informational support toward s-commerce intention, and the results of the other hypotheses are significant. Therefore, this research suggests practical implications that can be considered by companies or brands utilizing s-commerce to be able to improve buying process, which is used as a marketing strategy through social media to increase the intention of the consumer buying process through existing content created by the users.
\end{abstract}

Keywords: Social Commerce Constructs, Social Support, Perceived Usefulness, Perceived Risk, Social Commerce Intention.

\section{INTRODUCTION}

The development of the internet and e-commerce has created online purchases of products and services that can occur anytime and anywhere by many people, in line with the increasing popularity of social media, which has created a new direction in electronic commerce called social commerce (s-commerce) [1]. Indonesia is a growing market where users of social media platforms in Indonesia have increased by 10 million users $(6.3 \%)$ [2]. S-commerce has created value for consumers and online sellers, and it has created a situation that allows them to transaction products or services using content created by consumers through ratings and reviews, recommendations and referrals, forums and communities [3]. One of the social media that has stolen the attention in recent years is Tiktok which has become the most downloaded platform globally with more than 65 million installs and occupies the top position beating four platforms owned by Facebook [4].
This study aimed to determine the role of social commerce constructs (SCCs) in influencing perceptions of emotional support, support information, perceived usefulness, and perceived risk [5] [6], which in turn will increase trust in use in the buying process on TikTok as an e-commerce in Indonesia. Knowledge of s-commerce in this study refers to [3], [7]. The research includes consumer interactions that refer to the use of s-commerce on the TikTok platform in Indonesia, which aims to make an empirical contribution in Indonesia by analyzing the role of SCCs, emotional support, informational support, perceived usefulness, perceived risk, and trust that influence on s-commerce intention.

\section{LITERATURE REVIEW}

\subsection{Emotional Support}

Emotional support can be interpreted as a sense of empathy associated with a concern, understanding, love, the creation of encouragement between users in online communities that make them feel they receive support and are considered to be there, taken into 
account, and valued [7]. Emotional support focuses more on expressing the concerns of other users so that it can help solve a problem indirectly [8].

\subsection{Informational Support}

Informational support is a form of information that users of social networks intentionally create by offering input, opinions, suggestions that can provide relevant related information. As a result, users can solve the problems they are facing so that eventually, they can come up with new ideas or make better purchasing decisions [5] [9].

\subsection{Trust}

Trust is a belief that arises from a person in the ability and willingness of the other party to make exchanges to build a business, comply with norms, and keep his promises [10]. Trust can exist in an online context with greater relevance where there is a higher level of uncertainty [11] [12].

\subsection{Perceived Usefulness}

Perceived usefulness can be interpreted as users believing that using a particular system can improve their work performance [13]. A good system can create perceived usefulness, thus making users believe in the system and this is one of the Technology Acceptance Model (TAM) [13].

\subsection{Perceived Risk}

Perceived risk can be interpreted as consumer beliefs that can be experienced or felt due to negative and uncertain conditions experienced during the online purchase process [14] [15].

\subsection{Social Commerce Construct}

Social commerce constructs (SCCs) come from the existence of s-commerce through ratings and reviews, recommendations and referrals, forums and communities [3]. SCCs are divided into [7]:

- Ratings and reviews

- Recommendations and referrals

- Forums and communities

\subsection{Social Commerce Intention}

Social commerce intention is a measurement related to anticipating possible actions taken by consumers [16]. This new genre, s-commerce, tries to take advantage of commercial opportunities in SNSs by connecting through existing networks with the community to gain a commercial advantage.

\section{RESEARCH MODEL AND HYPOTHESIS}

SCCs allow users to generate and submit content to social networks to help other consumers get answers during the buying process, which can positively influence the intentions of other users to engage in various activities in s-commerce [4]. Interactions between users on social networks can directly affect scommerce intention [7]. Which can affect the behavior of other users and will lead to usage intentions with making the purchase process in s-commerce [6]. The hypothesis is:

\section{H1: SCCs positively influences s-commerce intention}

Information shared in the form of content on social networks or social media through SCCs will provide social support for consumers or other users, both in the form of emotional support and informational support that will help them during the decision-making process in s-commerce [17]. The main reason why people choose to join online forums and communities is to get social support, both emotionally and informationally, so they can exchange relevant information related to reviews or ratings, recommendations or referrals [16] and can get emotional social support because they feel supported by the existing community. The the hypothesis are:

\section{H2: SCCs positively influences emotional support \\ H3: SCCs positively influences informational support}

Users believe that using a certain system can improve job performance [12]. SCCs includes several aspects that technology can provide various sources related to knowledge and information generated through SCCs [6]. Furthermore, the interactions between these users can be easily accessed through social networks [18], because there are many different contents available, which can be helpful for other users in searching for related information, according to what they need or want. [19]. The hypothesis is:

\section{H4: SCCs positively influences perceived usefulness}

Lack of knowledge about sellers in e-commerce can also increase the influence of risks detrimental to online shopping [20]. Consumers use s-commerce constructs to produce content that can be used as valuable information for other users on social 
networks. It can certainly reduce the risk that other users in s-commerce may feel because they have obtained various product-related information from content created through the SCCs construct. As a result, perceived risk in s-commerce can become more challenging for consumers [21]. The hypothesis is:

\section{H5: SCCs negatively influences perceived risk}

Users on known social networks can more efficiently help transfer perceptions of trust to other relatively unknown users, which helps build trust [22]. For example, when users in s-commerce who already have high popularity in an online forum recommend a particular seller, other users tend to show a high level of trust in that seller [23]. SCCs can create social interaction and exchange of information to generate trust among their users [24]. The following hypothesis is:

\section{H6: SCCs positively influences trust}

Users' emotional and informational support has encouraged other users to use social networks to purchase products or services. Furthermore, this has encouraged other users to be more active in providing emotional support [16]. Therefore, socialization and social interaction between users through social media in social support can influence user decisions in the buying process in s-commerce [25]. The hypothesis are:

H7: Emotional support positively influences $s$ commerce intention

\section{H9: Informational support positively influences $s$ -} commerce intention

Theories about social support and trust transfer helped understand the effect of content created based on the experiences felt and shared on social networks that can create a sense of trust among users [22]. The emergence of user trust comes from social support that other users have provided with emotional support and information provided so that a sense of feeling is built in a relationship within social networks with user support through content to create a sense of trust [6]. Based on this description, the following hypothesis are:

\section{H8: Emotional support positively influences trust}

\section{H10: Informational support positively influences trust}

So it can be concluded that perceived usefulness can influence s-commerce intention, this is because high interaction in content created by users or other consumers online can affect product sales. Although, after all, users feel the benefits that can be felt from the content [26], the exchange of information obtained through eWOM in the form of posted content has shown that there can be a relationship with consumer behavior that can have an impact on other users' purchase intentions in s-commerce [25]. The following hypothesis is:

H11: Perceived usefulness positively influences $s$ commerce intention

The quality of content on social networks that consumers have posted can influence customers' trust [7]. So it can be said that perceived usefulness affects trust, this is because users can feel the benefits of content produced by users or consumers on social media, which can affect the emergence of trust that using a certain system can improve work performance and affect the trust of other users [17] [5]. The following hypothesis is:

\section{H12: Perceived usefulness positively influences trust}

The fact that social interaction occurs between users in a group is likely to be one of the main factors determining consumer behavior [27]. The users each have a great influence on the intentions of other users to use s-commerce [16]. Therefore, users and have an influence on s-commerce intention or intention in making the purchase process on social networks. The hypothesis is:

\section{H13: Perceived risk negatively influences s-commerce intention}

In the online buying process between buyers and sellers, there is no physical interaction in the process, thus making the perceived risk can be felt on trust, which is one of the essential factors that must be considered in s-commerce, so that it can help in reducing the perceived risk (perceived risk). risk) by consumers [16]. Perceived risk can affect user trust in the buying process on social networks [28]. The hypothesis is:

\section{H14: Perceived risk negatively influences trust.}

Trust in social networks can determine the credibility created due to content creation and activities carried out by other users [29]. So, it can be said that trust influences s-commerce intention because the content that has been produced by users or consumers online influences the intentions of other users in making purchasing decisions in s-commerce [5] [25]. The hypothesis is: 
H15: Trust positively influences s-commerce intention.

This is the proposed model in Figure 1.

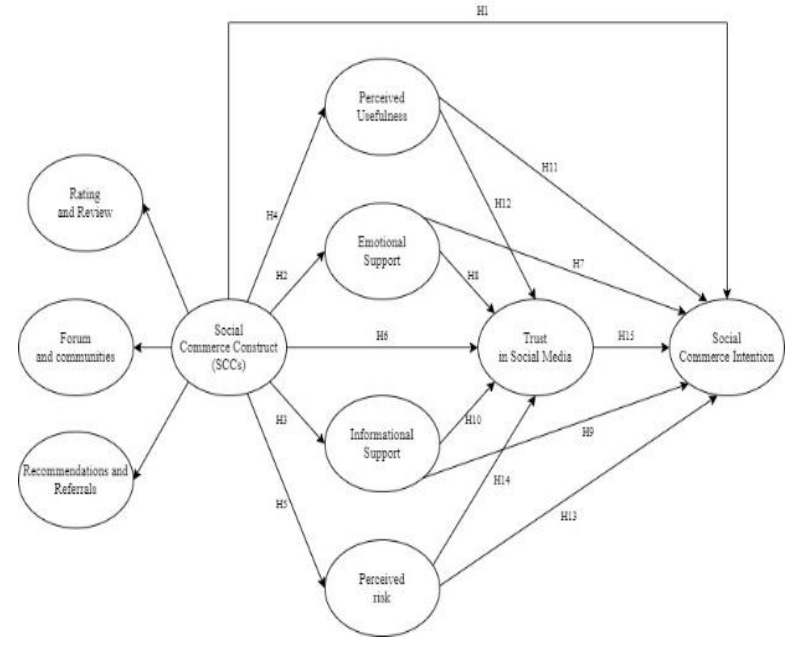

Figure 1. Research model

Source: Authors' own work

\section{RESEARCH METHODOLOGY}

\subsection{Data analysis and measurements}

This study refers to previous studies [7] and [30]. Items adapted from previous research; Social Commerce Constructs (SCCs) was measured through the scale of [5]. The proposed scale [9] was measured to Emotional support \& Informational support. Perceived usefulness is measured following the proposal [31]. Trust was measured through the scale of [16]. A survey was conducted using an online questionnaire to test the proposed model and with the items have been adopted from previous studies.

In collecting the results of respondents' answers using a questionnaire data collection technique based on an online questionnaire in the form of a google form, by distributing the questionnaire in the form of a link and posting it on social media, either through TikTok, Instagram, Facebook, and Whatsapp. Using the purposive sampling method and a Likert scale measuring instrument in five levels from strongly disagree with 1 to strongly agree with 5 . TikTok as scommerce users in Indonesia are the target population in this study. The population in this study are people who have used TikTok at least in the last three months and have made at least one purchase process on TikTok during that time. This study got 305 respondents. This study uses the PLS-SEM method with the SmartPLS program. This method is considered more suitable in applying actual conditions that can be used using a small number of samples and data that does not have to be normally distributed [32].

\subsection{Measurement and Structural Model}

This study were carried out concerning several assessment benchmarks. (Table 4.1) shows the value of validity and reliability as well as $R$ square $\left(R^{2}\right)$, where the results of this validity test are measured based on the value of the loading factor (LA) of the construct indicator, which can be said to be valid if the factor loading value of the model $>0.7$ as and the value of average variance extracted (AVE) $>0.5$. Furthermore, the reliability test results of each of the constructs of this study were tested by looking at the Composite Reliability (CR) and Cronbach's Alpha (CA) values of each construct. In order to achieve good reliability, the composite reliability value is > 0.7, and the Cronbach alpha value is $>0.7$ [18]. The $\mathrm{R}$-square value will range from 0 to 1 , where closer to 1 indicates the more significant influence of the selected independent variable [32].

Table 1. Results of Measurement \& Structural Model

\begin{tabular}{|c|c|c|c|c|c|c|}
\hline Variable & Indicator & LF & AVE & $\mathrm{CR}$ & $\mathrm{CA}$ & $\mathrm{R}^{2}$ \\
\hline \multirow{4}{*}{$\mathrm{RaR}$} & RaR1 & 0.862 & \multirow{4}{*}{0.761} & \multirow{4}{*}{0.927} & \multirow{4}{*}{0.895} & \\
\hline & RaR2 & 0.862 & & & & \\
\hline & RaR3 & 0.884 & & & & \\
\hline & RaR4 & 0.881 & & & & \\
\hline \multirow{4}{*}{ FC } & FC1 & 0.893 & \multirow{4}{*}{0.802} & \multirow{4}{*}{0.942} & \multirow{4}{*}{0.918} & \\
\hline & FC2 & 0.906 & & & & \\
\hline & FC3 & 0.906 & & & & \\
\hline & FC4 & 0.878 & & & & \\
\hline \multirow{4}{*}{$\operatorname{ReR}$} & ReR1 & 0.914 & \multirow{4}{*}{0.841} & \multirow{4}{*}{0.955} & \multirow{4}{*}{0.937} & \\
\hline & ReR2 & 0.925 & & & & \\
\hline & ReR3 & 0.918 & & & & \\
\hline & ReR4 & 0.913 & & & & \\
\hline \multirow{4}{*}{ ES } & ES1 & 0.914 & \multirow{4}{*}{0.846} & \multirow{4}{*}{0.955} & \multirow{4}{*}{0.937} & \multirow{4}{*}{0.498} \\
\hline & ES2 & 0.905 & & & & \\
\hline & ES3 & 0.935 & & & & \\
\hline & ES4 & 0.926 & & & & \\
\hline \multirow{3}{*}{ IS } & IS1 & 0.884 & \multirow{3}{*}{0.839} & \multirow{3}{*}{0.940} & \multirow{3}{*}{0.904} & \multirow{3}{*}{0.489} \\
\hline & IS2 & 0.929 & & & & \\
\hline & IS3 & 0.935 & & & & \\
\hline \multirow{4}{*}{ PU } & PU1 & 0.907 & \multirow{4}{*}{0.824} & \multirow{4}{*}{0.949} & \multirow{4}{*}{0.929} & \multirow{4}{*}{0.582} \\
\hline & PU2 & 0.896 & & & & \\
\hline & PU3 & 0.895 & & & & \\
\hline & PU4 & 0.933 & & & & \\
\hline \multirow{4}{*}{ PR } & PR1 & 0.709 & \multirow{4}{*}{0.774} & \multirow{4}{*}{0.931} & & \\
\hline & PR2 & 0.864 & & & 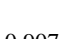 & \\
\hline & PR3 & 0.960 & & & 0.907 & 0.068 \\
\hline & PR4 & 0.962 & & & & \\
\hline & TR1 & 0.839 & & & & \\
\hline TR & TR2 & 0.878 & 0.761 & 0.905 & 0.842 & 0.676 \\
\hline & TR3 & 0.899 & & & & \\
\hline SCI & SCI1 & 0.895 & 0.749 & 0.947 & 0.932 & 0.771 \\
\hline
\end{tabular}




\begin{tabular}{|l|l|l|l|l|l|l|}
\hline & SCI2 & 0.915 & \multirow{4}{*}{} & & & \\
& SCI3 & 0.890 \\
\cline { 2 - 3 } & SCI4 & 0.790 & \multirow{4}{*}{} & & & \\
& SCI5 & 0.816 & & & \\
& SCI6 & 0.880 & & & & \\
\hline
\end{tabular}

Source: Authors' own work

Measuring discriminant validity using the method of [33], with discriminant validity was evaluated by a correlation between constructs. Therefore, the square root of the AVE value of each construct must be higher than all construct correlation values.

Table 2. Discriminant Validity Test Results

\begin{tabular}{|c|c|c|c|c|c|c|c|}
\hline & ES & IS & PR & PU & SCC & SCI & TR \\
\hline ES & 0.920 & & & & & & \\
\hline IS & 0.635 & 0.916 & & & & & \\
\hline PR & -0.267 & -0.262 & 0.880 & & & & \\
\hline PU & 0.629 & 0.754 & -0.280 & 0.908 & & & \\
\hline SCCs & 0.706 & 0.699 & -0.261 & 0.763 & 0.839 & & \\
\hline SCI & 0.673 & 0.727 & -0.381 & 0.817 & 0.774 & 0.866 & \\
\hline TR & 0.708 & 0.721 & -0.339 & 0.706 & 0.729 & 0.762 & 0.872 \\
\hline
\end{tabular}

Note: Values in bold are square root of the AVE

value of each construct

Source: Authors' own work

(Table 2) shows that the indicators used in this study have good discriminant validity in compiling each of the variables.

\subsection{Result of Hypothesis}

This section will explain the path coefficient test results to obtain the t-statistic parameters for each relationship path used in hypothesis testing. The level of precision or the limit of inaccuracy $(\alpha)=5 \%=0.05$ with a t-table value of 1.64 [32].

Table 3. Results of Hypothesis Testing

\begin{tabular}{|l|c|c|c|}
\hline & OS $(\mathrm{O})$ & $(|\mathrm{O} / \mathrm{STDEV}|)$ & P-values \\
\hline $\begin{array}{l}\text { SCCs } \rightarrow \\
\text { SCI }\end{array}$ & 0.199 & 3.357 & 0.001 \\
\hline $\mathrm{SCCs} \rightarrow$ ES & 0.706 & 25.287 & 0.000 \\
\hline $\mathrm{SCCs} \rightarrow$ IS & 0.699 & 17.026 & 0.000 \\
\hline $\mathrm{SCCs} \rightarrow$ PU & 0.763 & 25.335 & 0.000 \\
\hline $\mathrm{SCCs} \rightarrow$ PR & -0.261 & 4.826 & 0.000 \\
\hline $\mathrm{SCCs} \rightarrow$ TR & 0.222 & 3.449 & 0.001 \\
\hline ES $\rightarrow$ SCI & 0.065 & 1.330 & 0.184 \\
\hline ES $\rightarrow$ TR & 0.270 & 4.101 & 0.000 \\
\hline IS $\rightarrow$ SCI & 0.076 & 1.365 & 0.173 \\
\hline IS $\rightarrow$ TR & 0.262 & 3.355 & 0.001 \\
\hline PU $\rightarrow$ SCI & 0.395 & 6.462 & 0.000 \\
\hline PU $\rightarrow$ TR & 0.142 & 2.067 & 0.039 \\
\hline PR $\rightarrow$ SCI & -0.114 & 3.736 & 0.000 \\
\hline
\end{tabular}

\begin{tabular}{|l|c|c|c|}
\hline $\mathrm{PR} \rightarrow \mathrm{TR}$ & -0.101 & 2.622 & 0.009 \\
\hline $\mathrm{TR} \rightarrow$ SCI & 0.199 & 2.547 & 0.011 \\
\hline
\end{tabular}

Source: Authors' own work

Based on (Table 3) shows that almost all the hypotheses are acceptad, axcept $\mathrm{H} 7$ and $\mathrm{H} 8$ are not can be accepted.

\section{DISCUSSION AND CONCLUSION}

This study was conducted to determine the role of social commerce constructs (SCCs) in influencing perceptions of ES, IS, PU, and PR, which will increase the trustworthiness of use in the buying process on TikTok as s-commerce in Indonesia. The model in this study was tested using the PLS-SEM method with data from the survey results answered by 305 respondents who had met the criteria. The results of this study from 15 hypotheses are almost all significant, but two hypotheses are not significant: ES and IS toward SCI.

\section{IMPLICATIONS}

Implications of this research can provide knowledge and descriptions related to a broader vision of consumer behavior in the buying process involving on s-commerce. Sellers can take advantage of the SCCs to be able to increase usage intentions in the buying process on TikTok.

\section{CONTRIBUTION}

The contribution of the article to family firms can help in developing a family business by taking advantage of the presence of s-commerce through its construct, also to the Covid-19 pandemic, this can be a contribution to start utilizing s-commerce as much as possible because during this covid people are starting to shift to using s-commerce

\section{LIMITATION AND SUGGESTION}

The limitations of this study are that it only focuses on one s-commerce platform and covers a fairly wide area, and there is no age limitation for the respondents in this study, as well as brand specifications. Further research can do it on different s-commerce by providing generation, region boundaries, and brand specifications. 


\section{REFERENCES}

[1] Ali, A. A., Abbass, A., \& Farid, N. (2020). factors influencing customers purchase intention in social media. International Review of Management and Marketing, 10(5), 63-73. DOI: https://doi.org/10.32479/irmm.10097

[2] Statista. (2021, September 13). Global number of digital buyers 2014-2021. DOI: https://www.statista.com/statistics/251666/numb er-of-digital-buyers-worldwide/

[3] Hajli, M. (2013). A research framework for social commerce adoption. Information Management \& Computer Security, 21(3), 144-154. DOI: https://doi.org/10.1108/imcs-04-2012-0024

[4] Chan, J. (2021, September 10). Top Apps Worldwide for April 2020 by Downloads. Sensor Tower Blog. DOI: https://sensortower.com/blog/top-appsworldwide-april-2020-by-downloads

[5] Hajli, N. (2015). Social commerce constructs and consumer's intention to buy. International Journal of Information Management, 35(2), 183191.

DOI: https://doi.org/10.1016/j.ijinfomgt.2014.12.005

[6] Hajli, N., \& Sims, J. (2015). Social commerce: The transfer of power from sellers to buyers. Technological Forecasting and Social Change, 94, 350-358. DOI: https://doi.org/10.1016/j.techfore.2015.01.012

[7] Ventre, I., Mollá-Descals, A., \& Frasquet, M. (2020). Drivers of social commerce usage: a multi-group analysis comparing Facebook and Instagram. Economic Research-Ekonomska Istraživanja,34(1),570-589.

DOI: https://doi.org/10.1080/1331677x.2020.1799233

[8] Liang, T. P., \& Turban, E. (2011). Introduction to the Special Issue Social Commerce: A Research Framework for Social Commerce. International Journal of Electronic Commerce, 16(2), 5-14. DOI: $\quad$ https://doi.org/10.2753/jec10864415160201

[9] Liang, T. P., Ho, Y. T., Li, Y. W., \& Turban, E. (2011). What Drives Social Commerce: The Role of Social Support and Relationship Quality. International Journal of Electronic Commerce, 16(2), 69-90. DOI: https://doi.org/10.2753/jec1086-4415160204
[10] Schurr, P. H., \& Ozanne, J. L. (1985). Influences on Exchange Processes: Buyers' Preconceptions of a Seller's Trustworthiness and Bargaining Toughness. Journal of Consumer Research, 11(4), 939. DOI: https://doi.org/10.1086/209028

[11] Bai, Y., Yao, Z., \& Dou, Y. F. (2015). Effect of social commerce factors on user purchase behavior: An empirical investigation from renren.com. International Journal of Information Management, 35(5), 538-550. DOI:https://doi.org/10.1016/j.ijinfomgt.2015.04 .011

[12] Pavlou, P. A. (2003). Consumer Acceptance of Electronic Commerce: Integrating Trust and Risk with the Technology Acceptance Model. International Journal of Electronic Commerce, 7(3), 101-134. DOI: https://doi.org/10.1080/10864415.2003.1104427 5

[13] Davis, F. D. (1989). Perceived Usefulness, Perceived Ease of Use, and User Acceptance of Information Technology. MIS Quarterly, 13(3), 319. DOI: https://doi.org/10.2307/249008

[14] Park, S., \& Tussyadiah, I. P. (2016). Multidimensional Facets of Perceived Risk in Mobile Travel Booking. Journal of Travel Research, 56(7), 854-867. DOI: https://doi.org/10.1177/0047287516675062

[15] Pelaez, A., Chen, C. W., \& Chen, Y. X. (2017). Effects of Perceived Risk on Intention to Purchase: A Meta-Analysis. Journal of Computer Information Systems, 59(1), 73-84. DOI:https://doi.org/10.1080/08874417.2017.13 00514

[16] Hajli, M. N. (2014). The role of social support on relationship quality and social commerce. Technological Forecasting and Social Change, 87, 17-27. DOI: https://doi.org/10.1016/j.techfore.2014.05.012

[17] Hajli, N., Lin, X., Featherman, M., \& Wang, Y. (2014). Social Word of Mouth: How Trust Develops in the Market. International Journal of Market Research, 56(5), 673-689. DOI: https://doi.org/10.2501/ijmr-2014-045

[18] Stephen, A. T., \& Toubia, O. (2010). Deriving Value from Social Commerce Networks. Journal of Marketing Research, 47(2), 215-228. DOI: https://doi.org/10.1509/jmkr.47.2.215 
[19] Chen, J., Xu, H., \& Whinston, A. B. (2011). Moderated Online Communities and Quality of User-Generated Content. Journal of Management Information Systems, 28(2), 237-268. DOI: https://doi.org/10.2753/mis0742-1222280209

[20] Kaiser, S., \& Müller-Seitz, G. (2008). Leveraging Lead User Knowledge in Software Development-The Case of Weblog Technology. Industry and Innovation, 15(2), 199-221.

DOI: https://doi.org/10.1080/13662710801954542

[21] Featherman, M. S., \& Hajli, N. (2015). SelfService Technologies and e-Services Risks in Social Commerce Era. Journal of Business Ethics, 139(2), 251-269. DOI: https://doi.org/10.1007/s10551-015-2614-4

[22] Shi, Y., Sia, C. L., \& Chen, H. (2013). Leveraging social grouping for trust building in foreign electronic commerce firms: An exploratory study. International Journal of Information Management, 33(3), 419-428. DOI:https://doi.org/10.1016/j.ijinfomgt.2013.02 .001

[23] Lu, Y., Zhao, L., \& Wang, B. (2010). From virtual community members to $\mathrm{C} 2 \mathrm{C}$ e-commerce buyers: Trust in virtual communities and its effect on consumers' purchase intention. Electronic Commerce Research and Applications, 9(4), 346-360.

DOI: https://doi.org/10.1016/j.elerap.2009.07.003

[24] Shanmugam, M., Sun, S., Amidi, A., Khani, F., \& Khani, F. (2016). The applications of social commerce constructs. International Journal of Information Management, 36(3), 425-432. DOI:https://doi.org/10.1016/j.ijinfomgt.2016.01 .007

[25] Wang, X., Lin, X., \& Spencer, M. K. (2019). Exploring the effects of extrinsic motivation on consumer behaviors in social commerce: Revealing consumers' perceptions of social commerce benefits. International Journal of Information Management, 45, 163-175. DOI: https://doi.org/10.1016/j.ijinfomgt.2018.11.010

[26] Cheung, C. M., \& Thadani, D. R. (2012). The impact of electronic word-of-mouth communication: A literature analysis and integrative model. Decision Support Systems, 54(1), 461-470. DOI: https://doi.org/10.1016/j.dss.2012.06.008
[27] Bagozzi, R. P., \& Dholakia, U. M. (2002). Intentional social action in virtual communities. Journal of Interactive Marketing, 16(2), 2-21. DOI: https://doi.org/10.1002/dir.10006

[28] D’Alessandro, S., Girardi, A., \& Tiangsoongnern, L. (2012). Perceived risk and trust as antecedents of online purchasing behavior in the USA gemstone industry. Asia Pacific Journal of Marketing and Logistics, 24(3), 433460. https://doi.org/10.1108/13555851211237902

[29] Hajli, N., Sims, J., Zadeh, A. H., \& Richard, M. O. (2017). A social commerce investigation of the role of trust in a social networking site on purchase intentions. Journal of Business Research, 71, 133-141. DOI: https://doi.org/10.1016/j.jbusres.2016.10.004

[30] Ventre, I., \& Kolbe, D. (2020). The Impact of Perceived Usefulness of Online Reviews, Trust and Perceived Risk on Online Purchase Intention in Emerging Markets: A Mexican Perspective. Journal of International Consumer Marketing, 32(4), 287-299. DOI: https://doi.org/10.1080/08961530.2020.1712293

[31] Bianchi, C., and L. Andrews. 2012. Risk, trust, and con- sumer online purchasing behaviour: A Chilean perspec- tive. International Marketing Review $29 \quad$ (3):253-75. DOI: 10.1108/02651331211229750.

[32] Hair, J. F., Hult, G. T. M., Ringle, C. M., \& Sarstedt, M. (2017). A primer on partial least squares structural equation modeling (PLS-SEM) (2nd ed.). Thousand Oaks: Sage

[33] Fornell, C., \& Larcker, D. F. (1981). Evaluating structural equation models with unobservable variables and measurement error. Journal of Marketing Research, 18(1), 39-50. DOI: https://doi. org/10.2307/3151312 